\title{
국내 학교폭력 예방 프로그램의 효과에 관한 메타분석
}

\author{
윤초희(尹蕉熙 $)^{*}$ \\ 박상근(朴峖根) ${ }^{* *}$ \\ 신인수(申仁秀) ${ }^{*+*}$
}

\section{논문 요약}

이 연구는 메타분석 기법을 활용하여 학교폭력 예방 프로그램의 효과성을 종합적으로 평가하고자 하였다. 선 행연구들을 검색하기 위하여 학술연구정보서비스, 국회도서관, 국립중앙도서관, 한국심리학회 데이터베이스에 서 학교폭력, 공격성, 괴롭힘, 왕따, 비행, 가해자, 피해자, 예방, 효과크기 등을 키워드로 하여 자료를 검색하였 고, 검색된 자료 중에서 실험집단, 통제집단을 설정한 실험연구와 표준화된 측정도구를 사용한 논문을 기준으로 총 23편의 논문을 선정하였다. 이들 논문에서 추출한 총 96 개의 효과크기 값은 메타분석 전문 프로그램인 $\mathrm{CMA}$ (Comprehensive Meta Analysis) V2를 이용하여 분석하였다. 분석결과, 랜덤효과를 이용한 전체 프로그램 의 효과크기 값이 큰 것으로 나타났다. 프로그램 유형에 따른 효과크기 값을 비교한 결과, 학교폭력에 대한 문제 제기를 통해 폭력에 대한 인식과 태도 변화를 직접적으로 도모하는 직접교수 및 체험방식이 심리적 요인에 간접 적으로 개입하는 방식보다 효과크기가 유의하게 큰 것으로 나타났다. 이러한 프로그램 효과는 공격적 행동이나 실제 폭력의 감소뿐만 아니라 사회적 기술, 정서 개선 측면에서도 나타났다. 또한 대상연령이 고등학생일 때, 프로그램 실시 회기수가 증가할수록, 대집단보다는 소집단 활동에서 효과크기가 유의하게 큰 것으로 나타났다. 연구결과에 기초하여, 후속연구와 프로그램 운영에 대한 시사점이 논의되었다.

주요어 : 학교폭력, 예방 프로그램, 효과크기, 메타분석

* 제 1 저자. 동국대학교 교육학과 교수

** 동국대학교 교육대학원 석사졸업

*** 전주대학교 교육학과 교수 


\section{I. 서론}

최근 들어 학교폭력으로 인한 피해가 날로 심각해지면서 국가적 관심이 증가하고 있다. 청소 년폭력예방재단(2012)에 의하면, 학교폭력 가해율은 2007년 전체 청소년 대비 $15.1 \%$ 에서 2008년 $8.5 \%$ 로 감소하였으나 2009년 $12.4 \%, 2011$ 년 $15.7 \%$ 로 다시 상승하는 경향을 보이고 있다. 학교폭 력에 의한 피해율도 2006년 $17.3 \%$ 에서 2009년 9.4\%로 감소하였다가 2011년 $18.3 \%$ 로 큰 폭으로 증가하였다. 더욱이 최근의 학교폭력 가해학생 수는 2010년에 1만 9949명, 2011년에 2만 7021명 으로 급증하였고, 2012년도는 1학기에만 전년 동기 대비 $32 \%$ 증가한 1 만 7866 명인 것으로 나타 났다(교육과학기술부, 2012). 특히 폭력피해 후 '아무에게도 알리지 않았다'는 반응이 $32.5 \%$ 를 차지하여, 실제 학교폭력의 피해율과 가해율은 조사된 통계자료보다 더욱 높을 것으로 예측된다 (여성가족부, 2011).

학교폭력은 질적으로도 악화되고 있는데, 이는 학교폭력을 최초로 경험한 연령이 점차 낮아 지고 있고 학교폭력의 집단가해 비율이 증가하고 있는 것을 통해 확인할 수 있다. 청소년폭력예 방재단(2012)에 의하면, 학교폭력의 첫 발생 연령은 2010년 초등학교 1 3학년이 $17.5 \%, 4 \sim 6$ 학 년이 $35.9 \%$ 에서 2011 년에는 각각 $26.5 \%$ 와 $46.2 \%$ 로 연령대가 낮아지고 있으며, 학교폭력 가해자 가 2인 이상인 집단폭행 또한 2010년 66.2\%에서 2011년 67.9\%로 증가하였다. 이는 학교폭력이 이미 초등학교 저학년 시기에 시작되고 보다 조직화되고 있음을 말해주는 것이다. 아직 판단력 이 발달하지 않은 저연령대의 학생일수록 성장하면서 도덕적 개념이나 인성발달에서 더욱 어려 움을 가질 수 있고, 또한 가해학생이 집단화될 경우 공동행위로 인해 폭력행위에 대한 죄책감이 감소하게 되므로 개입이 더욱 어려워질 수 있다.

그동안 학교폭력의 예방과 근절을 위해 그 원인을 밝히고자 하는 연구가 꾸준히 이루어져 왔 다(예컨대, 김종미, 2004; 박영신, 김의철, 2001; 이규미, 이대식, 김영혜, 2003; 황진아, 2010). 학교 폭력의 원인을 파악하면 이러한 원인이 발생하지 않도록 미리 조건을 만들어줌으로써 학교폭력 을 예방하는 효과를 거둘 수 있다. 선행연구에 의해 밝혀진 원인들은 다양하지만, 크게 환경적인 요인과 개인적인 요인으로 구분할 수 있다. 환경적 요인으로는 가족의 핵가족화, 부모의 불량한 양육태도, 경제적 빈곤, 또래의 부정적인 가치관, 유해한 학교 주변환경과 폭력적인 대중매체의 영향 등이 주요 원인으로 지적되었다(김경숙, 1999; 이은미, 2000; 정진희, 2009; Bandura, 1973; Ladd \& Ladd, 1998). 개인적 요인으로는 인지·정서·행동적으로 나타나는 심리적 특성이 폭력발 생의 주요 원인으로 밝혀졌다(김종미, 2004; 황진아, 2010). 특히 인지적으로는 자아존중감이 낮 고 비합리적 신념이 강할수록, 정서적으로는 공격성과 불안수준이 높고 공감능력이 낮을수록, 그리고 행동적으로는 충동성이 높고 자기통제력이 낮을수록 학교폭력이 발생할 가능성이 높은 것으로 나타났다(이은미, 2000; Dykeman, et al., 1996; Marano, 1995; Rigby \& Slee, 1991; 
Salmivalli, 1998). 그러므로 학교폭력은 한 가지 요인으로 발생한다기보다는 개인의 심리적 · 기 질적인 요인과 환경적인 요인이 상호작용하여 발생하는 것으로 볼 수 있다.

이러한 학교폭력을 예방하기 위해 다양한 프로그램이 개발 - 실시되고 있다. 대표적으로 노르 웨이의 학자 Olweus(1993)가 개발한 프로그램이 전 세계적으로 사용되고 있다. 이 프로그램은 일반학생을 위한 1차 예방과 가/피해자 학생을 위한 2차 예방 프로그램으로 구성되어 있고, 학 교와 지역사회 개입을 모두 포함하는 다중적인 접근을 시도하고 있다. Olweus(1994)는 2년의 기간 동안 42 개의 학교를 대상으로 프로그램을 실시한 결과, 괴롭힘(bullying)과 반사회적 행동 이 감소되는 효과를 보여주었다. 최근에는 Vazsonyi, Belliston과 Flannery(2004)가 다양한 위험 군의 학생들에게 학교 기반의 폭력예방 프로그램을 실시한 결과 이들의 공격성이 감소되고 사 회적 기술이 향상되는 효과를 보여주었으며, Ngwe 등(2004)은 사회인지이론에 기반한 프로그램 을 실시한 후 폭력사용이 감소되는 효과를 보여주었다. Sprinkle(2005)은 초등학교 고학년 학생 들과 중학생을 대상으로 프로그램을 실시하여 역시 공격성이 감소되는 효과를 얻었다.

국내에서 개발된 프로그램도 다양한데(예컨대, 서울대학교 발달심리연구소에서 개발한 '시우 보우'(2005)와 ‘헬핑' 프로그램(2005), 삼성생명사회정신건강연구소에서 개발한 '한 번 더 생각해 봐!'(2005) 등), 이들 프로그램을 실시하여 학교폭력 예방에 대한 효과성을 검증한 연구들은 일부 영역에서 효과가 있음을 보여주었다. 예컨대, 이창숙(2012)은 '한 번 더 생각해봐!' 프로그램을 생태학적 관점으로 재구성하여 실시한 결과, 학교폭력에 대한 태도, 공격성, 자아존중감에서 변 화가 있음을 확인하였다. 양야기(2009)는 기존의 다양한 프로그램을 REBT(Rational Emotive Behavioral Therapy) 이론에 기초하여 재구성하여 실시한 결과, 학교폭력에 대한 태도 개선, 분 노와 공격성 감소 등의 효과를 이끌어냈다. 놀이를 활용한 장금순(2005)의 연구에서도 예방 프로 그램은 폭력에 대한 허용도와 태도개선에 긍정적인 효과가 있는 것으로 나타났다. 1년 동안 폭 력예방 캠페인을 벌이고 추적 조사한 이훈구 등(2000)의 연구에서는 학교폭력 피해 및 가해비율 이 유의하게 감소한 것으로 나타났다.

종합하면, 학교폭력 예방 프로그램은 폭력에 대한 태도와 인식 강화, 정서변화, 공격성 및 실 제 폭력사용의 감소에 긍정적인 효과가 있는 것으로 평가할 수 있지만, 가정이나 지역사회의 개 입 없이는 장기적인 효과를 보장하기가 어렵고 개별 프로그램의 효과에 대한 분석만으로는 다 양한 프로그램의 비교와 종합적인 평가가 어렵다는 한계가 있다. 일례로, 이창숙(2012)은 학생에 게서 나타난 변화를 연구자뿐만 아니라 교사와 학부모를 통해서도 관찰할 필요가 있음을 지적 하였고, 단기적인 효과뿐만 아니라 장기적인 변화를 추적 조사해야 한다고 강조하였다. 학생뿐 만 아니라 교사, 부모, 지역사회를 포괄하는 보다 다차원적인 전략의 부재 문제는 많은 예방 프 로그램이 가지고 있는 한계이기도 하다. 프로그램은 주로 학교라는 공간에서 실시되기 때문에 사회적 맥락과 문화의 영향을 다룰 수 있는 보다 복합적인 접근이 필요하고, 프로그램 개선을 
위해서는 학생의 행동변화 뿐만 아니라 교사와 학부모의 인식변화까지도 포함하는 보다 포괄적 인 평가가 이루어질 필요가 있다(양야기, 2009).

또한 시행되는 프로그램의 이론적 토대와 구성요소가 모두 다르기 때문에, 이에 따라 중재되 는 행동특성과 각 효과크기도 다르게 나타날 수 있다. 특히 개별 프로그램은 특정 변인(인지, 정서, 사회, 행동 등)에 초점을 두고 개발되기 때문에 한 영역에서는 효과적일 수 있지만 다른 영역에서는 효과적이지 않을 수 있다(조성호, 1999). 더 큰 문제는 학교폭력이 단순히 가해자와 피해자로 이루어져 있기 보다는 소수의 가해자와 피해자, 그리고 다수의 방관자로 구성되어 있 다는 점이다. 이러한 다수의 방관자는 언제든 가해자나 피해자가 될 가능성이 있으며 이들의 묵 인과 방관 속에서 폭력의 피해가 지속되는 경우가 많다. 따라서 가해자와 피해자에 대한 개입으 로 그치는 것이 아니라 방관자(또는 일반학생)까지 포함하는 학교 전체적인 개입이 이루어지지 않는다면 언제든지 다시 폭력이 발생할 가능성이 있다(Olweus, 1997). 이처럼 프로그램의 이론 적 토대, 개입하고자 하는 심리적 변인, 구체적인 프로그램 내용, 지역사회와의 연계 여부 등에 따라 효과들이 각기 다르게 나타나기 때문에, 향후 보다 효과적인 학교폭력 예방 프로그램을 개 발하기 위해서는 이러한 다양한 변인의 영향을 종합적으로 분석할 필요가 있다.

다양한 세부 요인들의 효과에 대한 통합적인 비교분석 방법으로 메타분석이라는 대안이 제시 되고 있다. Glass(1976)에 의하면, 메타분석은 '분석에 대한 분석’으로 과거 유사한 주제를 연구 한 결과를 통합하여 분석함으로써 전반적인 경향성을 확인할 수 있게 하는 방법이다. 심리치료 분야에서는 이미 이러한 메타분석 방법이 다양하게 사용되고 있다(예컨대, 고용남, 2010; 김윤지, 2007; 박승민, 2009; 임영아, 2013; 장명희, 2012). 그러나 학교폭력과 관련하여 메타분석을 수행 한 연구는 최운선(2005)의 연구가 유일하며, 이마저도 학교폭력에 영향을 미치는 개인, 학교, 가 정, 또래 요인에 관한 메타분석에 국한되어 있다. 미국의 경우에도 학교폭력 관련 메타분석 연구 는 많으나, 학교폭력 예방 프로그램의 효과에 관한 메타분석 연구는 소수에 불과하다.

일례로, Derzon과 Wilson(1999)은 학교기반의 폭력예방 프로그램이 언어적 폭력, 신체적 폭 력, 공격성 등을 포함하는 반사회적 행동의 감소에 전반적으로 성공적이라는 결론을 내렸다. 특 히 이 연구에서 멘토링, 자기통제 프로그램, 또래중재, 교과활동 내에서 이루어지는 프로그램들 이 모두 효과적인 것으로 나타났다. 총 28개의 실험연구를 메타분석한 Mytton 등(2002)의 연구 또한 프로그램 유형과 상관없이 학교기반의 폭력 예방 프로그램이 학생의 실제 공격적 행동을 감소시키는 데 효과적임을 보여주었다. 이 연구에서 흥미로운 결과는 프로그램 진행 시 남학생 집단보다는 혼성집단이나 여학생집단을 대상으로 할 때 효과가 더 크게 나타났다는 점이다. 아 마도 폭력 예방교육에 대한 민감성이 여학생에게서 (혹은 여학생이 있는 환경에서) 더욱 크게 작용하는 것으로 추론해볼 수 있지만, 성에 의한 프로그램 효과의 조절여부는 후속연구를 통해 재검증될 필요가 있다. Hahn 등(2007)의 연구 또한 학교 전체적으로 이루어지는 학교폭력 예방 
프로그램이 유아원(pre-kindergarten)부터 고등학교에 이르기까지 전반적인 폭력감소를 가져왔 으며, 사용된 전략(예컨대, 정보제공, 인지 및 정서개입, 사회적 기술 훈련 등)이 모두 효과가 있 음을 보여주었다. 그러나 이들 연구는 주로 효과가 나타난 결과변인에 초점을 두고 있어 프로그 램의 어떠한 측면이 이러한 효과를 가져왔는지에 대해 명확히 밝히지 못한다는 한계가 있다.

이에 반해, Park-Higgerson 등(2008)의 연구는 프로그램의 특성에 따른 효과크기의 차이분석 을 시도하고 있어, 공격성/폭력 감소를 가져온 프로그램의 성공요인을 직접적으로 확인할 수 있게 해준다. 이 연구는 총 26개의 논문을 대상으로 메타분석을 실시한 결과, 이론 기반의 프로 그램보다 이론에 기반하지 않은 프로그램이 오히려 더 큰 효과가 있음을 보여주었다. 또한 학교 교육과정뿐만 아니라 부모, 또래, 지역사회에 동시에 개입하는 다중접근 방식은 효과가 없었던 반면, 학교 교육과정 내에서 이루어지는 단일접근 방식은 폭력감소에 더욱 효과적인 것으로 나 타났다. 한편, 일반학생보다는 위험집단을 대상으로 한 프로그램이, 그리고 비전문가보다 전문 가가 진행한 프로그램에서 효과크기가 더욱 크게 나타난 점은 예측되었던 결과이다. 그럼에도 단일접근 방식을 제외하고는 이들 하위집단 간에 통계적으로 유의한 차이가 나타나지 않았다. 이에 대해 저자들은 다중접근 방식의 사용 여부 '자체'보다는 프로그램이 그 목적과 취지에 맞게 얼마나 충실히 운영되었는지(프로그램 충실도)와 학교기관과 학부모간의 긴밀한 협력관계가 더 중요함을 지적하고 있다. 다중접근은 Olweus를 비롯한 많은 학교심리학자들이 학교폭력 개입 의 주요 요소로서 강조하고 있지만, 이러한 요소가 효과적으로 작용하기 위해서는 다양한 교육 주체의 적극적인 관여와 긴밀한 협력체계 등이 필수적으로 요구됨을 알 수 있다.

우리나라에서는 학교폭력의 심각성이 날로 증가하고 있음에도 불구하고 실제로 예방 및 개입 프로그램을 실시하여 그 효과성을 검증한 연구들이 매우 드물다. 프로그램 또한 미국의 경우처 럼 전체 학교를 기반으로 장기적으로 운영되기 보다는, 소수집단을 대상으로 비체계적이고 단기 적으로 실시되는 경우가 대부분이라 학교폭력을 효과적으로 중재하고 예방하기에는 한계가 있 다. 또한 이들 프로그램은 학교폭력의 심각성에 따라 충분한 사전준비 없이 산발적으로 개발 운영되어 온 측면이 강하므로, 보다 실제적이고 장기적인 효과를 가져 오기 위해서는 먼저 이들 프로그램의 효과를 종합적으로 분석 · 검토할 필요가 있다. 최근에 급격하게 증가하고 있는 학교 폭력에 대한 논의와 교육이 연구결과 등 증거에 기반하기(evidence based practice in education) 보다는 상식이나 암묵적 신념에 의해 이루어지는 경우가 많은 점도 이 연구를 시도한 계기가 되었다. 아직 연구가 많이 축적되지는 않았지만, 예비분석을 통해 향후 학교폭력 예방 프로그램 의 개선점을 도출하고 보다 효과적인 프로그램 운영을 위한 기초자료를 제공하는 것은 의미 있 는 일일 것이다. Borenstein, Hedges, Higgins와 Rothstein(2009)에서도 지적하고 있듯이, 메타분 석의 의의는 연구들의 현 상태(present status)를 알려주고, 후속연구의 방향을 제시해 주는 것이 다. 이에 본 연구는 과거에 실시되었던 학교폭력 예방 프로그램의 효과에 관한 메타분석을 실시 
하여, 개별 프로그램이 갖는 다양한 요인(프로그램 특성, 개입된 심리적 변인, 진행방식, 참여대 상 등)에 따라 프로그램의 효과크기가 어떻게 달라지는지를 검증하고자 하였다. 이들 요인은 프 로그램 효과에 관한 메타분석에서 주요변인으로 사용되는 것들이며, 이 연구에서도 선행연구의 동향에 따라 크게 독립변인(프로그램 특성), 종속변인(결과변인), 그리고 기타 조절변인(진행방 식, 참여대상 등)으로 분류하여 분석하였다. 구체적인 연구문제는 다음과 같다.

첫째, 학교폭력 예방 프로그램의 전체적인 효과크기는 어떠한가?

둘째, 학교폭력 예방 프로그램의 하위 집단별 효과크기는 어떠한가?

\section{ㅍ. 연구방법}

\section{1. 분석대상}

연구의 메타분석에 쓰일 데이터를 수집하기 위하여 한국교육학술정보원(www.riss.kr), 국회 전자도서관, 국립중앙도서관, 한국심리학회 데이터베이스에서 학교폭력, 공격성, 괴롭힘, 왕따, 가해, 피해, 예방, 효과크기 등의 키워드를 사용하여 자료를 검색하였다. 1990년부터 2013년까지 출판된 모든 석·박사학위 논문과 학술지에 게재된 논문을 검색하여, 총 217 편의 논문을 수집하 였다. 이들 논문 중 석·박사학위 논문은 107 편, 학술지 논문은 110 편이었다.

연구의 데이터로 사용하기 위해, 수집한 논문들을 아래와 같은 기준을 적용하여 다시 분류하 였다. 첫째, 실험집단과 통제집단을 분류하여 실험집단에 일정한 처치를 한 후 사전-사후 검사를 실시한 실험연구만 포함시켰다. 실험연구라 해도 통제집단이 존재하지 않거나 소수의 사례를 분 석한 사례연구, 설문지를 조사한 양적연구는 자료에서 제외하였다. 그리고 이러한 실험연구 중 연구대상자들의 심리적 요인에 직접적으로 개입하는 학교폭력 예방 프로그램인 경우만 포함시 켰다. 예컨대, 학교폭력 예방 프로그램이 학교 주변환경을 정비하거나 교내 순찰 프로그램을 도 입하는 등 환경적인 영향에 개입한 경우는 자료에서 제외하였다. 둘째, 표준화된 측정도구로 사 전-사후 검사를 실시하여 통계적인 수치(평균, 표준편차 등)가 명시된 경우만 포함시켰다. 독립 변인이 심리적 개입을 시도한 학교폭력 예방 프로그램이라 할지라도, 사후 검사로 단순히 만족 도를 조사한 경우와 행동관찰이나 인터뷰 등을 통해 효과를 평가한 경우는 자료에서 제외하였 다. 셋째, 명시적으로 학교폭력 예방 프로그램으로 특정한 연구들만 포함시켰다. 심리치료나 기 타 중재 프로그램과는 달리, 실제 학교에서 이루어지는 학교폭력 예방 프로그램은 다수의 일반 학생을 대상으로 실시되는 경우가 많다. 일부 가해자나 피해자 대상의 프로그램이 있긴 하지만, 이는 예방보다는 주로 심리치료에 중점을 둔다. 이들 심리치료 프로그램은 학교폭력 예방 프로 
그램과 통합하여 메타분석을 수행하기에는 다소 이질적인 프로그램이라고 할 수 있다. 따라서 대상자를 선정할 때 한 학년 전체, 혹은 무작위로 선정된 한 학급 전체 등 불특정 다수를 선정하 거나 혹은 사전검사를 통해 공격성 등이 높은 학생을 선정한 예방 프로그램을 포함시키되, 이들 의 심리치료를 목적으로 한 프로그램은 제외하였다. 위 기준에 부합되지 않은 논문을 제외하고 재선정한 논문은 총 23 편으로, 석사논문 11 편, 박사논문 5 편, 학술지 논문 7 편이었다. 분석대상 논문을 선정하기 위한 과정은 [그림 1]과 같다.

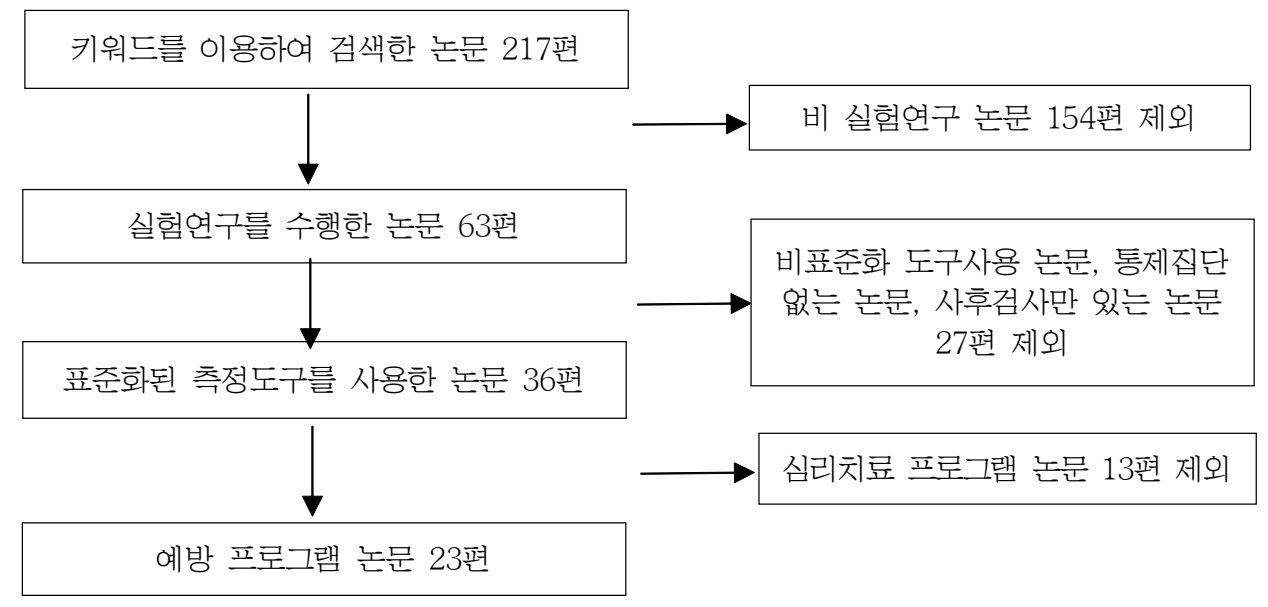

[그림 1] 분석대상 논문 선정과정

\section{2. 자료코딩}

위의 기준으로 선정된 논문을 연구 출판년도, 연구 출판유형, 독립변인인 예방 프로그램의 특 성, 종속변인인 프로그램의 효과유형, 그 외 프로그램 참여자 연령, 인원수, 실시횟수 등으로 범 주화하여 코딩하였다. 우선 대부분의 프로그램이 강의, 체험활동, 역할놀이, 매체활용 등 다양한 활동들로 구성되어 있기 때문에 프로그램을 내용으로 분류하기 어려운 점이 있었다. 이에 따라, 본 연구에서는 학교폭력을 직접적으로 언급하고 체험하게 하는 직접교육 방식과 대상자의 인지, 정서, 행동에 긍정적인 변화를 주고자 하는 간접연관 방식으로 프로그램을 분류하였다. 종속변 인인 프로그램의 효과 역시 매우 다양한 형태로 구성되어 있었으며, 본 연구에서는 이를 크게 사회적 기술(대인관계, 사회성 등), 정서(불안, 우울, 자아존중감, 공감 등), 폭력인식 및 태도, 실 제적인 가/피해 경험 및 폭력행동의 4 가지로 분류하였다. 프로그램 참여자는 초등학생, 중학생, 고등학생으로 범주화하여 분류하였으며, 프로그램의 진행 절차는 프로그램 진행자, 프로그램의 참여 인원 수, 총 진행 회기 수, 주당 회기 진행 수, 1 회기 당 시간으로 분류하였다. 연속변인인 
프로그램 참여 인원 수, 프로그램 총 진행 회기 수와 관련해서는 메타회귀분석을 실시하였다.

자료코딩을 위해, 교육심리 전문가, 현장에서 청소년상담을 담당하는 상담사, 측정평가 전문 가가 함께 코딩스킴을 개발하여 자료를 코딩하였고, 코딩 범주 간에 불일치가 나타난 경우 충분 한 논의를 통해 해결하였다. 연구에 사용된 분석대상 논문 23 편의 출판년도와 출판유형, 참여자 연령, 프로그램의 특성과 효과 영역 등에 대한 정보는 <표 $1>$ 에 제시되었다.

<표 1> 분석대상 논문의 특징

\begin{tabular}{|c|c|c|c|c|c|c|c|}
\hline 일련 & 연구자(연도) & $\begin{array}{l}\text { 출판 } \\
\text { 유형 }\end{array}$ & $\begin{array}{l}\text { 참여자 } \\
\text { 연렁 }\end{array}$ & $\begin{array}{c}\text { 실험/통제 } \\
\text { 인원 }\end{array}$ & $\begin{array}{l}\text { 실시 } \\
\text { 횟수 }\end{array}$ & $\begin{array}{c}\text { 프로그램 } \\
\text { 특성 }\end{array}$ & $\begin{array}{c}\text { 프로그램 } \\
\text { 효과 }\end{array}$ \\
\hline 1 & $\begin{array}{c}\text { 김동일, } \\
\text { 박알뜨리, } \\
\text { 이기정(2008) }\end{array}$ & 학술지 & 초등학생 & $174 / 224$ & $6 \sim 8$ & $\begin{array}{l}\text { 학교폭력 } \\
\text { 직접교육 }\end{array}$ & $\begin{array}{l}\text { 대인관계 } \\
\text { 정서인식 } \\
\text { 감정이입 } \\
\text { 공감 }\end{array}$ \\
\hline 2 & 김현정(2013) & 석사논문 & 초등학생 & $28 / 27$ & 4 & $\begin{array}{l}\text { 학교폭력 } \\
\text { 직접교육 }\end{array}$ & $\begin{array}{c}\text { 학교폭력 태도 } \\
\text { 사회기술 }\end{array}$ \\
\hline 3 & 김혜진(2002) & 석사논문 & 중학생 & $33 / 32$ & 10 & $\begin{array}{l}\text { 학교폭력 } \\
\text { 직접교육 }\end{array}$ & $\begin{array}{c}\text { 학교폭력에 대한 허용도 } \\
\text { 학교폭력행위 가능성 } \\
\text { 폭력문화 허용도 } \\
\text { 교우의 또래 괴롭힘 } \\
\text { 성향 } \\
\text { 학교적응 }\end{array}$ \\
\hline 4 & 도기봉(2007) & 학술지 & 고등학생 & $10 / 10$ & 8 & $\begin{array}{l}\text { 학교폭력 } \\
\text { 간접연관 }\end{array}$ & 자아존중감 \\
\hline 5 & 박송지(2010) & 석사논문 & 중학생 & $35 / 44$ & 4 & $\begin{array}{l}\text { 학교폭력 } \\
\text { 직접교육 }\end{array}$ & $\begin{array}{c}\text { 학교폭력 발생인식 } \\
\text { 학교폭력에 대한 허용도 } \\
\text { 학교폭력행위 가능성 }\end{array}$ \\
\hline 6 & 박은숙(2008) & 석사논문 & 고등학생 & $15 / 15$ & 10 & $\begin{array}{l}\text { 학교폭력 } \\
\text { 간접연관 }\end{array}$ & 대인관계 척도 \\
\hline 7 & 서미경(2007) & 석사논문 & 중학생 & $40 / 40$ & 10 & $\begin{array}{l}\text { 학교폭력 } \\
\text { 직접교육 }\end{array}$ & $\begin{array}{c}\text { 교우의 또래괴롭힘 } \\
\text { 학교폭력에 대한 허용도 } \\
\text { 학교폭력행위 가능성 } \\
\text { 폭력에 대한 인식 } \\
\text { 공격성 검사 }\end{array}$ \\
\hline 8 & 서춘래(2007) & 박사논문 & 초등학생 & $11 / 11$ & 12 & $\begin{array}{l}\text { 학교폭력 } \\
\text { 간접연관 }\end{array}$ & $\begin{array}{c}\text { 공격신념 } \\
\text { 스트레스 지각 및 대처 } \\
\text { 집적거림 } \\
\text { 공격성 }\end{array}$ \\
\hline 9 & $\begin{array}{c}\text { 양미진, 김은영, } \\
\text { 이상희(2008) }\end{array}$ & 학술지 & 초등학생 & $113 / 251$ & 13 & $\begin{array}{l}\text { 학교폭력 } \\
\text { 직접교육 }\end{array}$ & $\begin{array}{c}\text { 공감능력 } \\
\text { 배려행동 } \\
\text { 교우관계 } \\
\text { 학교생활 만족도 }\end{array}$ \\
\hline
\end{tabular}




\begin{tabular}{|c|c|c|c|c|c|c|c|}
\hline 10 & 양야기(2009) & 박사논문 & 중학생 & $78 / 61$ & 12 & $\begin{array}{l}\text { 학교폭력 } \\
\text { 직접교육 }\end{array}$ & $\begin{array}{c}\text { 학교폭력태도 } \\
\text { 분노 } \\
\text { 공격성 }\end{array}$ \\
\hline 11 & 유평수(2005) & 학술지 & 중학생 & $52 / 53$ & 12 & $\begin{array}{l}\text { 학교폭력 } \\
\text { 간접연관 }\end{array}$ & $\begin{array}{c}\text { 신체폭력 } \\
\text { 심리폭력 } \\
\text { 언어폭력 } \\
\text { 집단폭력 } \\
\text { 금픔폭력 } \\
\text { 성희롱 }\end{array}$ \\
\hline 12 & $\begin{array}{c}\text { 이은희, 김혜진, } \\
\text { 홍경자(2002) }\end{array}$ & 학술지 & 중학생 & $33 / 32$ & 10 & $\begin{array}{l}\text { 학교폭력 } \\
\text { 직접교육 }\end{array}$ & $\begin{array}{c}\text { 학교폭력에 대한 허용도 } \\
\text { 학교폭력행위 가능성 } \\
\text { 폭력문화 허용도 } \\
\text { 교우의 또래괴롭힘 } \\
\text { 학교적응 }\end{array}$ \\
\hline 13 & 이정희(2011) & 석사논문 & 초등학생 & $30 / 30$ & 12 & $\begin{array}{l}\text { 학교폭력 } \\
\text { 간접연관 }\end{array}$ & $\begin{array}{c}\text { 학교폭력에 대한 허용도 } \\
\text { 학교폭력에 대한 태도 } \\
\text { 학교폭력 발생 시 } \\
\text { 대처태도 } \\
\text { 친구관계 만족도 } \\
\text { 선생님관계 만족도 } \\
\text { 학교 만족도 }\end{array}$ \\
\hline 14 & 이창숙(2012) & 박사논문 & 초등학생 & $25 / 26$ & 12 & $\begin{array}{l}\text { 학교폭력 } \\
\text { 직접교육 }\end{array}$ & $\begin{array}{c}\text { 학교폭력 태도 } \\
\text { 공격성 } \\
\text { 자기존중감 }\end{array}$ \\
\hline 15 & 이채원(2013) & 박사논문 & 고등학생 & $12 / 12$ & 12 & $\begin{array}{l}\text { 학교폭력 } \\
\text { 간접연관 }\end{array}$ & $\begin{array}{c}\text { 자아존중감 } \\
\text { 학교응집력 } \\
\text { 학교폭력에 대한 태도 }\end{array}$ \\
\hline 16 & 임정란(2013) & 석사논문 & 초등학생 & $12 / 15$ & 8 & $\begin{array}{l}\text { 학교폭력 } \\
\text { 간접연관 }\end{array}$ & 방관적 태도 \\
\hline 17 & 장금순(2005) & 박사논문 & 초등학생 & $39 / 38$ & 8 & $\begin{array}{l}\text { 학교폭력 } \\
\text { 직접교육 }\end{array}$ & $\begin{array}{c}\text { 학교폭력에 대한 허용도 } \\
\text { 학교폭력에 대한 태도 } \\
\text { 학교폭력 발생 시 대처 } \\
\text { 태도 } \\
\text { 친구관계 만족도 } \\
\text { 선생님과의 관계 만족도 } \\
\text { 학교 만족도 }\end{array}$ \\
\hline 18 & $\begin{array}{c}\text { 정성희, } \\
\text { 송현주(2012) }\end{array}$ & 학술지 & 초등학생 & $40 / 40$ & 5 & $\begin{array}{l}\text { 학교폭력 } \\
\text { 간접연관 }\end{array}$ & $\begin{array}{l}\text { 학교적응 } \\
\text { 자아존중감 } \\
\text { 공격성 }\end{array}$ \\
\hline 19 & 정혜승(2008) & 석사논문 & 중학생 & $16 / 16$ & 16 & $\begin{array}{l}\text { 학교폭력 } \\
\text { 간접연관 }\end{array}$ & $\begin{array}{l}\text { 학교폭력 태도 } \\
\text { 공격성 } \\
\text { 자아 존중감 } \\
\text { 학교적응 척도 } \\
\text { 학교폭력 척도 }\end{array}$ \\
\hline
\end{tabular}




\begin{tabular}{c|c|c|c|c|c|c|c}
\hline 20 & 탁안희(2012) & 석사논문 & 초등학생 & $22 / 22$ & 10 & $\begin{array}{l}\text { 학교폭력 } \\
\text { 직접교육 }\end{array}$ & 공격성 \\
\hline 21 & 한숙경(2007) & 석사논문 & 고등학생 & $30 / 30$ & 13 & $\begin{array}{l}\text { 학교폭력 } \\
\text { 직접교육 }\end{array}$ & $\begin{array}{c}\text { 분노조절 } \\
\text { 자아 존중감 }\end{array}$ \\
\hline 22 & $\begin{array}{c}\text { 허승희, 최태진 } \\
\text { (2008) }\end{array}$ & 학술지 & 초등학생 & $11 / 11$ & 15 & $\begin{array}{c}\text { 학교폭력 } \\
\text { 간접연관 }\end{array}$ & $\begin{array}{c}\text { 자기중심성 } \\
\text { 공격성 } \\
\text { 친사회성 } \\
\text { 갈등해결방식 }\end{array}$ \\
\hline 23 & 홍현정(2008) & 석사논문 & 중학생 & $36 / 36$ & 10 & $\begin{array}{l}\text { 학교폭력 } \\
\text { 직접교육 }\end{array}$ & 분노조절 \\
\hline
\end{tabular}

\section{3. 자료분석 방법}

실험집단과 통제집단 사전-사후 설계 연구의 효과크기 계산을 위해, 본 연구에서는 실험집단 의 사전-사후 검사결과와 통제집단의 사전-사후 검사결과를 사용해서 '표준화된 평균차 변화' 효 과크기(the standardized mean change difference)를 계산하였다(Morris \& DeShon, 2002). 이를 위해서는 프로그램 실시 전과 실시 후에 실험집단과 통제집단 각각의 차이에 대한 표준화된 평 균차이의 계산이 필요하다. 실험집단 및 통제집단의 사전-사후 효과크기 계산은 일반적인 효과 크기 (d)를 계산하는 방법과 다르다. 효과크기 계산을 위한 순서는 다음과 같다.

먼저 실험집단의 사전-사후 차이(Ytrt - Xtrt)를 사전평균의 표준편차로 나눈 값 $\left(g^{t r t}\right)$ 과 통제 집단의 사 전-사후 차이(Ytrt - Xcrt)를 사전평균의 표준편차로 나눈 값 $\left(g^{c r t}\right)$ 을 구한다. 계산 계산공식은 다음과 같다.

$$
g^{t r t}=\frac{Y_{t r t}-X_{t r t}}{S_{x}}, g^{c r t}=\frac{Y_{c r t}-X_{c r t}}{S_{x}}
$$

$Y^{t r t}$ 는 처치집단의 사후평균값을 의미하고, $X^{t r t}$ 는 처치집단의 사전평균값을 의미한다. $Y^{c r t}$ 는 통제집단의 사후평균값을 의미하고, $X^{c r t}$ 는 통제집단의 사전평균값을 의미한다. $S_{x}$ 는 처치집단과 통제집단의 사전검사 평균값의 표준편차를 나타낸다.

모든 표준화된 평균차 변화 효과크기를 계산하는 과정에서, 작은 표본으로 인한 편차교정(corrected for small-sample bias)의 과정을 거쳤다. 교정된 효과크기 $\left(d_{i}\right)$ 는 다음의 공식에 의해 도출된다.

$$
d_{i}^{t r t}=\frac{4\left(n_{i}-2\right)}{4 n_{i}-5}\left(g^{t r t}\right), d_{i}^{c r t}=\frac{4\left(n_{i}-2\right)}{4 n_{i}-5}\left(g^{c r t}\right)
$$


측정된 효과크기의 분산은 다음과 같은 공식에 의해 유도된다.

$$
\operatorname{Var}\left(d^{t r t}\right)=\frac{4\left(1-r^{t r t}\right)+\left(g^{t r t}\right)^{2}}{2 n^{t r t}}, \operatorname{Var}\left(d^{c r t}\right)=\frac{4\left(1-r^{c r t}\right)+\left(g^{c r t}\right)^{2}}{2 n^{c r t}}
$$

$\mathrm{r}$ 은 실험집단과 처치집단에서의 사전-사후 검사점수의 상관계수이다. 표준화된 평균차 변화 효과크기의 분산은 $V_{d}=\operatorname{Var}\left(d^{t r t}\right)+\operatorname{Var}\left(d^{c r t}\right)$ 로 계산되고, 측정된 효과크기의 표준오차는 분산의 제곱근으로 구할 수 있다.

$$
S E_{d}=\sqrt{V_{d}}
$$

연구의 사례수 크기에 따른 가중치를 부여하기 위해 Hedges와 Olkin(1985)의 방법을 활용하였다. 전체적인 효과크기를 측정하는데 있어서, 먼저 동질성 검사를 통해 각 연구에서 추출된 효과크기들 이 같은 모집단에서 추출된 것인지를 검사할 필요가 있다. 이 연구에서는 표준화된 평균차 효과크기 를 계산하기 위해 SAS 프로그램을 이용하여 <표 2>와 같이 동질성 검사를 실시하였다. 검사결과, 선행연구들에서 추출된 효과크기는 서로 이질적인 것으로 나타났다 $(Q=397.998 d f=95, p<.001)$. 따라 서 본 연구에서는 랜덤효과 모형을 이용하여 전체적인 효과크기를 측정하고, 연구의 특성을 반영한 범주형 변인에 따라 하위그룹 분석과 메타회귀분석을 실시하여 각각의 효과크기들을 비교하였다. 랜덤효과 모형을 이용한 전체 효과크기와 각각의 하위그룹 분석은 Comprehensive Meta Analysis ver 2.2 프로그램을 이용하여 계산하였다. CMA(http://www.meta-analysis.com/index.php)는 사회 과학 및 의료보건 분야의 메타분석 전문가 들이 개발한 메타분석 전용 윈도우 프로그램으로, 기존의 SPSS, SAS, STATA등의 syntax를 이용해야 하는 어려움을 해결하고 기존의 방법론적 논의를 장착한 가장 대표적인 메타분석 프로그램이다.

<표 2> 동질성 검정 결과

\begin{tabular}{ccccccc}
\hline $\mathrm{K}$ & $Q$ & $p$ & $-95 \% \mathrm{CI}$ & $\mathrm{ES}$ & $+95 \% \mathrm{Cl}$ & $\mathrm{SE}$ \\
\hline 96 & 397.998 & .000 & .336 & .378 & .420 & .021 \\
\hline
\end{tabular}

$\mathrm{K}$ : 효과크기수; $Q$ : 동질성 검정 통계량; $p$ : 동질성 검정 통계량에 대한 유의수준 값 $95 \%$ $\mathrm{CI}: 95 \%$ 신뢰구간; $\mathrm{ES}$ : 효과크기; SE: 표준오차

계속해서, 메타분석 결과의 타당성 확보를 위해 출판편의 검증을 실시하였다. 출판편의 검증 방법으로 분석대상에서 빠진 연구논문(missing studies)을 감안하여 새로운 효과크기를 재산정 
하는 방법도 있지만, 다른 한편으로는 통계적으로 유의한 결과가 더 많이 출판되고 유의하지 않 은 더 많은 연구들이 출판되지 않은 문제로 인해 초래되는 불완전성의 문제를 해결하는 방법으 로 Orwin(1983)의 안전성계수(fsn)를 사용한다. 본 연구에서 안전성계수는 추정된 효과크기 값 이 '작은 효과'를 나타내는 .2 값이 되려면 존재가 파악되지 않은 몇 편의 연구물이 필요한지를 나타낸다. 예컨대, 분석대상 논문 23편에 대한 전체 효과크기는 .641이고 이 효과크기가 .2가 되 기 위해서는 효과가 전혀 없다는 결과가 나온 연구 50 편이 필요하므로, 전체 효과크기에 대한 출판편의가 없는 것으로 판단된다.

\section{III. 연구결과}

\section{1. 전체 효과크기}

총 23편의 논문을 대상으로 96개의 효과크기를 산출하였다. 분석결과, 랜덤효과 분석으로 도 출된 전체 효과크기 값은 .641이고 $95 \%$ 신뢰구간에 해당하는 값은 .545 .737로 나타나, 신뢰구 간 내에 0이 포함되지 않으므로 통계적으로 유의하다고 할 수 있다. Cohen(1992)은 효과크기가 $E S \geq .50$ 인 경우 중간 정도의 효과가 있으며 $E S \geq .80$ 인 경우 효과가 큰 것으로 해석하였다. 이를 적용해 보면, 학교폭력 예방 프로그램의 전체 효과는 중간보다 다소 높은 효과크기를 가진 것으로 볼 수 있다. 이를 정리한 결과는 <표 3>과 같다.

<표 3> 전체 평균 효과크기

\begin{tabular}{|c|c|c|c|c|c|c|c|}
\hline \multirow[t]{2}{*}{ 모델 } & \multirow[t]{2}{*}{ 효과크기 수 } & \multirow[t]{2}{*}{ 평균 효과크기 } & \multirow[t]{2}{*}{ 표준오차 } & \multicolumn{2}{|c|}{$\begin{array}{c}\text { 평균의 95\% } \\
\text { 신뢰구간 }\end{array}$} & \multirow[t]{2}{*}{$Q$} & \multirow[t]{2}{*}{$f_{S n}$} \\
\hline & & & & 하한값 & 상한값 & & \\
\hline Random & 96 & .641 & .049 & .545 & .737 & 397.998 & 50.715 \\
\hline
\end{tabular}

주: $Q=$ 동질성 계수, $f_{S n}=$ 안정성 계수

계속해서, 통제집단과 실험집단의 차이를 분석하기 위해 비중복 백분위(percentiles of non-overlap: U3)를 산출한 결과, 효과크기 .641에 해당하는 $Z$ 값은 .738로 나타났다. 이를 비중복 백분위 $U 3$ 값으로 변환하면 $73.9 \%$ 가 된다. 이는 정규분포곡선 상에서 아무런 처치가 없는 통제 집단의 평균을 $50 \%$ 라고 했을 때, 예방 프로그램을 실시한 실험집단의 평균이 $73.9 \%$ 가 되어 평 균값이 약 $23.9 \%$ 상승함을 의미한다([그림 2] 참조). 각 연구별 효과크기의 값을 한 눈에 볼 수 
있도록 forest plot을 나타낸 결과는 [그림 3]과 같다. 효과크기 값은 최소 .100 에서 최대 2.579까 지 다양하게 분포되어 있음을 알 수 있다.

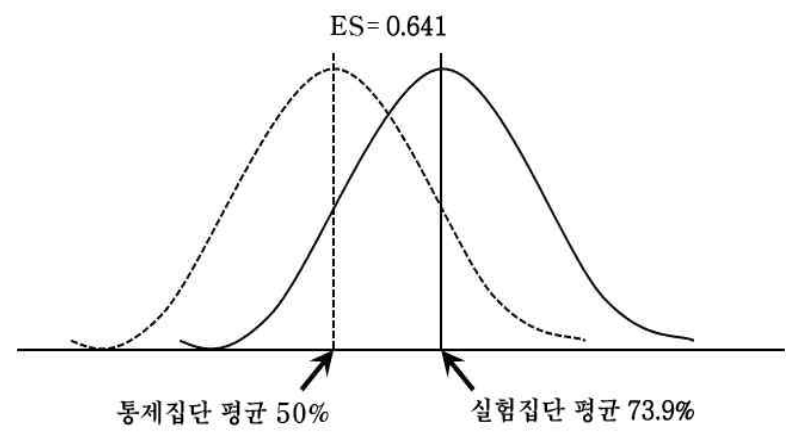

[그림 2] 정규분포 상에서의 평균 효과크기

\section{Meta Analysis}

\begin{tabular}{|c|c|c|c|c|c|c|c|c|c|c|c|c|c|}
\hline \multirow{25}{*}{ 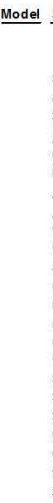 } & \multirow[t]{2}{*}{ Study name } & \multicolumn{3}{|l|}{$\underline{\text { Subgroup within study }}$} & \multicolumn{5}{|c|}{ Statistics for each study } & \multicolumn{4}{|c|}{ Hedges's $\mathrm{g}$ and $95 \% \mathrm{Cl}$} \\
\hline & & & $\underset{g}{\text { Hedges's }}$ & $\begin{array}{l}\text { Standard } \\
\text { error }\end{array}$ & Variance & $\begin{array}{l}\text { Lower } \\
\text { limit }\end{array}$ & $\begin{array}{c}\text { Upper } \\
\text { limit }\end{array}$ & $z$-Value & $p$-Value & & & & \\
\hline & 김동일 바앝뜨리 이기정 2008 & 8 Combined & 0.158 & 0.034 & 0.001 & 0.091 & 0.224 & 4.658 & 0.000 & & & 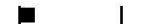 & \\
\hline & 김련정 2013 & Combined & 0.679 & 0.199 & 0.040 & 0.289 & 1.070 & 3.409 & 0.001 & & & & \\
\hline & 김혜진 2008 & Combined & 0.311 & 0.111 & 0.012 & 0.094 & 0.527 & 2811 & 0.005 & & & - & \\
\hline & 도기몽 2007 & Combined & 0.065 & 0.321 & 0.103 & 0.237 & 1.494 & 2700 & 0.007 & & & & \\
\hline & 밥송지 2010 & Combined & 1.026 & 0.149 & 0.022 & 0.733 & 1.319 & 6863 & 0.000 & & & & \\
\hline & 박은숙 2008 & 19.000 & 2125 & 0.449 & 0.201 & 1.245 & 3.004 & 4734 & 0.000 & & & & \\
\hline & 서미결 2007 & Combined & 0.382 & 0.100 & 0.010 & 0.186 & 0.578 & 3815 & 0.000 & & & - & \\
\hline & 서쿤래 2007 & Combined & 2020 & 0.256 & 0.066 & 1.518 & 2522 & 7.892 & 0.000 & & & & \\
\hline & 양미지닌 김은영 이상희 2008 & Combined & 0.240 & 0.063 & 0.004 & 0.116 & 0.364 & 3.780 & 0.000 & & & $=$ & \\
\hline & 양야기 2009 & Combined & 0.266 & 0.099 & 0.010 & 0.072 & 0.459 & 2692 & 0.007 & & & - & \\
\hline & 유펑수 2005 & combined & 0.346 & 0080 & 0.006 & 0.189 & 0.502 & 4.329 & 0.000 & & & - & \\
\hline & 이은희 김혜진 홍결자 2002 & Combined & 0.308 & 0.110 & 0.012 & 0.098 & 0.525 & 2789 & 0.005 & & & $\rightarrow$ & \\
\hline & 이정희 2011 & Combined & 0.734 & 0.108 & 0.012 & 0.522 & 0.945 & 6.808 & 0.000 & & & - & \\
\hline & 이창숙 2012 & Combined & 1.302 & 0.145 & 0.021 & 1.018 & 1.585 & 9001 & 0.000 & & & & \\
\hline & 이채원 2013 & Combined & 0.846 & 0.171 & 0.029 & 0.511 & 1. 182 & 4941 & 0.000 & & & $\rightarrow$ & \\
\hline & 임정란 2013 & 90.000 & 2.579 & 0.514 & 0.254 & 1.571 & 3.506 & 5.017 & 0.000 & & & & \\
\hline & 장금순 2005 & Combined & 0.563 & 0.096 & 0.009 & 0.375 & 0.751 & 5.877 & 0.000 & & & - & \\
\hline & 정성희 송현주 2012 & Combined & 0.100 & 0.128 & 0.016 & -0.151 & 0.361 & 0.782 & 0.434 & & & & \\
\hline & 정혜승 2009 & Combined & 1.495 & 0.183 & 0.033 & 1.136 & 1.853 & 8.177 & 0.000 & & & & \\
\hline & 탁안희 2012 & 78.000 & 0.724 & 0.306 & 0.094 & 0.124 & 1.324 & 2367 & 0.018 & & & $\longrightarrow$ & \\
\hline & 한속경 2007 & Combined & 1.033 & 0.192 & 0.037 & 0.656 & 1.410 & 5370 & 0.000 & & & $\rightarrow$ & \\
\hline & 허승의 최태진 2008 & Combined & 0.881 & 0.165 & 0.027 & 0.558 & 1.204 & 5.344 & 0.000 & & & & \\
\hline & 홍현정 2008 & 88.000 & 0.504 & 0.237 & 0.066 & 0.040 & 0.969 & 2128 & 0.033 & & & & \\
\hline \multirow[t]{3}{*}{ Fixed } & & & 0.378 & 0.021 & 0.000 & 0.336 & 0.420 & 17.745 & 0.000 & & & 1 & 1 \\
\hline & & & & & & & & & & -4.00 & -2.00 & 0.00 & 4.00 \\
\hline & & & & & & & & & & & Favours A & F avours B & \\
\hline
\end{tabular}

Meta Analysis

[그림 3] 각 연구별 효과크기 값의 forest plot

\section{2. 프로그램 특성에 따른 효과크기 차이}

전체 평균 효과크기 분석에서 동질성이 기각되었으므로, 세부적인 효과크기는 모두 랜덤효과 분석을 통해 추출된 값을 이용하였다. 본 연구에서 독립변인으로 상정한 학교폭력 예방 프로그 
램은 특정한 이론을 기반으로 하기 보다는 다양한 활동을 중심으로 구성되어 있었다. 또한 연구 데이터로 이용된 모든 논문의 매뉴얼과 진행방식이 미리 정해져 있는 구조화 진행방식을 따르 고 있었고, 내담자가 자발적으로 프로그램을 진행하는 방식보다 진행자가 주도적으로 프로그램 을 진행하는 방식으로 구성되어 있었다. 프로그램 내용이 대동소이하고 진행방식이 유사함에 따 라, 내용에 따라 프로그램을 분류하기 보다는 폭력에 대한 메시지전달의 직접성과 간접성 여부 로 유형을 분류하였다. 13 개 프로그램이 학교폭력을 직접적으로 교육하고 체험하게 하는 직접교 육 방식을 사용하였고, 10 개 프로그램이 대상자의 심리적 요인에 간접적으로 개입하여 변화를 도모하는 방식을 사용하였다. 두 유형의 프로그램 효과크기는 .875 와 .489로 나타났다(<표 $4>$ 참 조). 여기서 $Q b$ 값은 비교하고자 하는 특성에서 이질성(Heterogeneity)을 확인하기 위한 값으로 직접교육 방식과 간접연관 방식 간에 이질성이 존재하기 때문에 $(p<.001)$, 두 유형 간에 유의한 차이가 있다고 할 수 있다. 즉, 간접연관 방식보다는 직접교육 및 체험방식이 더 효과적이라고 볼 수 있다.

<표 4> 프로그램 특성에 따른 효과크기

\begin{tabular}{|c|c|c|c|c|c|c|}
\hline 프로그램 & 효과크기 수 & 평균 효과크기 & 표준오차 & $Q b$ & $d f b$ & $p$ \\
\hline 직접교육 & 45 & .875 & .078 & \multirow{2}{*}{15.618} & \multirow{2}{*}{1} & \multirow{2}{*}{.000} \\
\hline 간접연관 & 51 & .489 & .059 & & & \\
\hline
\end{tabular}

\section{3. 종속변인에 따른 효과크기 차이}

각 연구마다 개입하는 종속변인은 1 6가지 이상으로 매우 다양하였으며, 인식, 정서, 사회, 행동적 특성 모두를 개입하는 연구와 이 중 한 가지에만 개입하는 연구들이 혼재되어 있었다. 이를 크게 폭력에 대한 인식 및 태도, 정서, 사회기술, 실제 공격성 및 폭력행동으로 분류하여 종속변인 별 효과크기 값을 분석한 결과는 <표 5>에 제시되었다. 가장 큰 효과가 있었던 영역은 실제 공격성 및 폭력행동으로 효과크기 값은 807 이었다. 효과가 가장 적은 영역은 정서 영역으 로 효과크기 값은 .514 로 나타났다. 효과가 가장 적었다 하더라도 Cohen의 효과크기 분류에 의 하면 중간정도의 효과를 보이고 있음을 알 수 있다(ES $\geq .50)$ 
<표 5> 종속변인에 따른 효과크기

\begin{tabular}{ccccccc}
\hline 종속변인 & 효과크기 수 & 평균 효과크기 & 표준오차 & $Q b$ & $d f b$ & $p$ \\
\cline { 1 - 4 } 폭력인식 및 태도 & 33 & .697 & .081 & & & \\
\cline { 1 - 4 } 정서 & 34 & .514 & .078 & & & \\
\cline { 1 - 4 } 사회기술 & 12 & .629 & .143 & & & \\
\cline { 1 - 4 } 공격성/폭력행동 & 17 & .807 & .124 & & \\
\hline
\end{tabular}

\section{4. 프로그램 진행방식 및 대상자에 따른 효과크기 차이}

프로그램의 효과는 프로그램 운영횟수나 운영시간, 참여자 등에 따라 달라질 수 있다. 독립변 인인 프로그램의 특성 이외에, 프로그램의 효과를 조절할 수 있는 변인들을 조절변인으로 상정 하여 이들 특성에 따른 효과크기를 분석하였다. 사용된 변인은 주당 회기 수, 1 회기 당 진행시간, 프로그램 진행자의 형태 등 프로그램 진행방식과 대상자 연령이다. 먼저, 대상자의 연령은 ‘초등 학생', ‘중학생', ‘고등학생'의 세 수준으로 구분하였으며, 대상자 연령에 따른 차이분석 결과는 <표 6>에 제시되었다. 표에서 볼 수 있는 것처럼, 효과크기는 고등학생이 가장 크고 다음으로 초등학생, 중학생 순으로 나타났다.

<표 6> 대상자 연령에 따른 효과크기

\begin{tabular}{|c|c|c|c|c|c|c|}
\hline 연령 & 효과크기 수 & 평균 효과크기 & 표준오차 & $Q b$ & $d f b$ & $p$ \\
\hline 초등학생 & 48 & .633 & .066 & \multirow{3}{*}{7.663} & \multirow{3}{*}{2} & \multirow{3}{*}{.022} \\
\hline 중학생 & 37 & .543 & .076 & & & \\
\hline 고등학생 & 11 & 1.044 & .164 & & & \\
\hline
\end{tabular}

계속해서, 프로그램의 주당 회기 수, 회기 당 진행시간에 따른 효과크기 분석 결과는 <표 7> 과 <표 8>에 제시되었다. 프로그램 주당 실시 회기 수에 따른 효과크기 값은 주 1회기가 .723, 주 2회기 이상이 .602로 주 1회기가 다소 높게 나타났다. 또한 각 회기 당 진행 시간에 따른 효과 크기 값은 1 시간 미만이 $.660,1$ 시간 이상이 .472 , 진행시간을 표기하지 않은 경우가 .742로 나타 났다. 
<표 7> 주당 회기 수에 따른 효과크기

\begin{tabular}{ccccccc}
\hline 회기 수 & 효과크기 수 & 평균 효과크기 & 표준오차 & $Q b$ & $d f b$ & $p$ \\
\hline 주 1회기 & 34 & .723 & .089 & & & \\
\cline { 1 - 3 } 주 2회기 이상 & 62 & .602 & .058 & & 1.314 & 1 \\
\hline
\end{tabular}

<표 8> 1회기 당 진행시간에 따른 효과크기

\begin{tabular}{ccccccc}
\hline 진행시간 & 효과크기 수 & 평균 효과크기 & 표준오차 & $Q b$ & $d f b$ & $p$ \\
\cline { 1 - 4 } 1시간 미만 & 73 & .660 & .057 & & & \\
\cline { 1 - 4 } 1시간 이상 & 13 & .472 & .134 & 2.126 & 2 & .345 \\
\cline { 1 - 3 } 미표기 & 10 & .742 & .155 & & & \\
\hline
\end{tabular}

마지막으로, 프로그램의 진행자에 따른 효과크기의 차이를 분석하였다. 학교폭력 예방 프로그 램은 단순한 강의보다는 대상자들이 프로그램에 실제 참여하고 체험하는 형태가 대부분이므로 프로그램 진행자의 역량에 따라 효과에서 차이가 날 수 있다. 진행자의 형태에 따른 효과크기 분석 결과는 <표 9>에 제시되었다. 전문가(임상전문가 및 연구자)가 직접 진행한 경우 효과크기 는 .623, 비전문가(담임교사 및 기타)가 진행한 경우 효과크기는 .508이었다. 진행자의 형태를 표 시하지 않은 경우 .784 로 나타났다.

<표 9> 진행자에 따른 효과크기

\begin{tabular}{ccccccc}
\hline 진행자 & 효과크기 수 & 평균 효과크기 & 표준오차 & $Q b$ & $d f b$ & $p$ \\
\cline { 1 - 4 } 전문가 & 63 & .623 & .061 & & & \\
\cline { 1 - 4 } 비전문가 & 10 & .508 & .138 & 2.76 & 2 & .250 \\
\cline { 1 - 4 } 미표기 & 23 & .784 & .108 & & & \\
\hline
\end{tabular}

\section{5. 연속변인에 대한 메타회귀분석 결과}

메타회귀분석을 위해 총 실시 회기수와 총 참여 인원수가 사용되었다. 프로그램 총 실시 회기 수는 최소 4 회기 최대 16회기까지이며, 총 참여 인원수는 최소 11 명 최대 174 명까지이다. 우선 총 프로그램 실시 회기수에 따른 메타회귀분석 결과를 살펴보면(<표 10> 참조), 회기수가 많아 질수록 효과크기가 증가하는 것을 확인할 수 있다 $(t=4.61, p<.001)$. 또한 총 참여 인원수에 따른 
회귀분석 결과, 인원이 증가할수록 효과가 떨어지는 것으로 나타났다 $(t=-10.280, p<.001)$.

<표 10> 연속변인에 대한 메타회귀분석 결과

\begin{tabular}{cccccc}
\hline \multicolumn{2}{c}{ 연속변인 } & $\beta$ & $S E$ & $t$ & $p$ \\
\hline 회기수 & slope & .056 & .072 & .770 & .440 \\
\hline & intercept & .034 & .007 & 4.610 & .000 \\
\hline 인원수 & slope & .671 & .035 & 18.805 & .000 \\
\hline & intercept & -.002 & .000 & -10.280 & .000 \\
\hline
\end{tabular}

\section{II. 논의 및 결론}

이 연구는 학교폭력 예방 프로그램의 효과성을 메타분석하여 종합적으로 평가하는 데 목적이 있다. 연구결과를 요약하고 논의하면 다음과 같다.

첫째, 연구에서 선정된 23편의 논문에서 산출된 96개의 효과크기를 랜덤효과 모형으로 분석 한 결과, 학교폭력 예방 프로그램의 효과가 큰 것으로 나타났다. 즉, 예방 프로그램을 실시한 실 험집단이 실시하지 않은 통제집단에 비하여 다양한 심리적 변인에서 효과가 있는 것으로 나타 났다. Park-Higgerson 등(2008)의 연구에서 대부분의 효과크기가 작게 나타난 점과는 대조적이 다. 아마도 미국의 경우, 단기적 실험연구보다는 장기간의 학교기반 폭력 예방프로그램을 중심 으로 메타분석을 시도하고 있어 상대적으로 효과크기가 작게 나타났을 수 있다. 실험연구의 경 우, 프로그램의 실행과 관리가 보다 철저하고 집중적으로 이루어지기 때문이다. 또한 실험연구 의 경우, 대개 효과가 나타난 연구를 중심으로 출판되는 경향이 있기 때문에 본 연구에서 효과크 기가 크게 나타났을 수 있다. 그럼에도, 국내에서 실시된 기존의 학교폭력 예방 프로그램이 (단 기적이나마) 폭력에 대한 인식, 정서, 사회, 행동 등 다양한 결과변인에서 전반적으로 효과가 있 음을 알 수 있다.

둘째, 독립변인에 따른 효과크기 차이분석에서, 대부분의 프로그램은 특정한 이론을 기반으로 하기 보다는 역할극, 동아리활동, 놀이, 문제해결, 매체활용 등 다양한 활동을 중심으로 구성되 어 있고 주로 학교 안에서의 교육에 주력하고 있어, 구성내용을 중심으로 세분화하기가 어려운 점이 있었다. 이에 따라, 학교폭력에 대한 직접적인 문제제기를 통해 학생들의 태도와 행동변화 를 이끌어내고자 하는 직접교수 및 체험방식과 폭력을 언급하진 않지만 관련된 심리적 요인에 간접적으로 개입하는 간접연관 방식으로 구분하여 효과크기의 차이를 분석하였다. 분석 결과, 
직접교수 방식으로 이루어진 프로그램의 효과크기 값이 유의하게 높은 것으로 나타났다. 전반적 으로 폭력을 직접적으로 거론하면서 이를 의식하게 만드는 방법이 보다 효과적임을 알 수 있다. 셋째, 종속변인에 따른 차이 분석에서는 다양한 결과변인에서 효과가 있었지만 영역 간 차이 는 유의하지 않은 것으로 나타났다. 즉, 선행연구에서 사용된 폭력예방 프로그램은 폭력에 대한 인식과 공격성/실제적인 폭력사용뿐만 아니라 사회적 기술 계발, 부정적 정서의 감소, 자아존중 감과 같은 긍정적 정서의 강화에도 효과가 있는 것으로 나타났다. 미국의 선행연구(Derzon \& Wilson, 1999; Mytton et al., 2002; Park-Higgerson et al., 2008)들이 주로 궁극적인 결과변인인 공격성과 폭력 감소에서 효과를 보여주었다면, 본 연구는 실제적인 가/피해 경험 및 폭력행위뿐 만 아니라 다양한 정서 및 사회성 변인에서도 프로그램의 효과가 있음을 보여주고 있다. 특히 사후검사에서의 실험-통제집단의 차이가 아니라 각 집단의 사전-사후 검사점수의 차이를 이용 하여 평균 효과크기를 분석한 것이므로, 프로그램 실시 전후의 변화양상과 정도를 확인할 수 있 다는 점에서 연구결과가 보다 의미있다고 할 수 있겠다. 그럼에도 다른 변인보다 실제폭력 및 공격성 감소에서 효과크기가 가장 크게 나타난 결과는 사용된 프로그램의 직접적인 목표가 다 양한 심리적 변인에 대한 개입보다는 실제 폭력과 관련된 인식과 행동변화라는 점에서 기인한 듯하다. 프로그램의 장기적 효과는 추수조사를 통해 확인할 필요가 있지만, 비교적 단기간의 실 험연구에서 사용된 프로그램이 다양한 측면에서 효과가 있음을 확인할 수 있다.

넷째, 프로그램 진행방식 및 참여자에 따른 효과크기의 차이분석 결과, 고등학생 대상 프로그 램의 효과크기가 가장 컸고, 비전문가보다는 전문가가 진행한 프로그램의 효과가 큰 것으로 나 타났다. 또한 주당 1 회기, 회기당 1 시간 미만의 활동이 효과가 가장 큰 것으로 나타났다. 그러나 대부분의 효과크기가 .50 이상으로 비교적 큰 효과크기를 보여주고 있고, 하위집단 간 효과크기 는 대상연령을 제외하고 통계적으로 유의하지 않은 것으로 나타났다. 고등학생의 경우 가장 큰 효과크기를 보여주었는데, 이는 고등학생 집단에서 효과크기가 가장 크게 나타난 기존연구의 결 과와도 부합하는 것이다(Derzon \& Wilson, 1999; Hahn et al., 2007; Park-Higgerson, 2008). 예 방 프로그램이 인식변화나 실제 행동변화에 초점을 두고 있는 경우가 많아 인과성에 대한 추상 적 사고나 도덕적 관념이 보다 발달하는 고등학생의 경우 더 효과가 있는 것으로 해석해볼 수 있으나, 오히려 초등학생이 중학생보다 효과크기가 높게 나타난 점은 추후연구를 통해 재검증될 필요가 있다. Hahn 등(2007)의 메타분석연구에서도 프로그램 실시 이후 폭력감소 비율은 고등 학생, 초등학생, 중학생의 순으로 나타나 특히 사춘기가 시작되는 연령이 폭력에 더욱 취약하다 는 것을 알 수 있지만, 보다 명확한 규명을 위해서는 후속연구들이 필요하다.

다섯째, 연속변인에 대한 메타회귀분석 결과, 프로그램의 실시 회기수가 증가할수록, 참여 인 원수가 적을수록 더 효과적인 것으로 나타났다. 프로그램 기간이 길어질수록 효과크기가 증가하 는 것은 Mytton 등(1999)의 메타분석연구에서도 확인되었다. 따라서 프로그램 진행 시 10회 미 
만의 단기적인 프로그램보다는 장기적인 프로그램 실시가 필요하고, 대규모 인원을 대상으로 하 기보다 소집단으로 진행하는 것이 보다 적절할 것으로 보인다. 대규모 강의식 수업이나 단기적 활동은 태도나 인식에서의 변화는 가져올지 모르지만, 오랫동안 고착화된 습관이나 행동 상의 변화를 이끌어내기는 어려울 수 있기 때문이다.

연구결과를 종합하면, 전반적으로 학교폭력 예방 프로그램은 대상자들의 다양한 종속변인을 조절하고 변화시키는 데 효과가 있으며, 특히 학교폭력에 대한 직접적인 문제제기를 통해 그 위 험성을 알리는 직접교수 및 체험방식이 보다 효과적이라고 할 수 있다. 또한 참여자가 고등학생 일 때, 프로그램의 회기수가 증가할수록, 그리고 참여자 수가 적은 소규모 프로그램일수록 프로 그램의 효과가 더 크다고 할 수 있겠다.

이 연구는 상대적으로 적은 양의 자료를 대상으로 하였기 때문에 연구결과를 일반화하는 데 한계가 있지만, 학교폭력 예방 프로그램 연구의 현재 상태를 진단하고 향후 연구의 방향을 제시 한다는 점에서 의의가 크다고 할 수 있다. 연구결과를 기반으로, 후속 연구와 프로그램 운영을 위한 시사점을 제시하면 다음과 같다. 첫째, 폭력예방 프로그램을 실시하는 과정에서 표준화된 측정도구를 사용하고 실험조건을 정확히 충족시킨 연구가 부족하다. 연구를 위해 논문을 표집할 때 초기 50여 편 이상의 논문을 표집하였으나 많은 연구들이 통제집단을 설정하지 않았거나 사 전-사후 설계를 하지 않았고 또한 표준화되지 않은 측정도구를 사용하여 연구에서 제외되었다. 추후에는 보다 정교한 실험설계와 측정도구를 사용하여 연구가 이루어질 필요가 있다.

둘째, 이 연구에서 분석된 많은 연구들은 프로그램 진행 이후의 효과의 지속성을 판별할 수 있는 추수연구를 수행하지 않았다. 비록 추수연구를 진행한 연구들은 예방효과가 지속된 것으로 보고하고 있으나, 이를 조사한 연구의 수가 적어서(3편) 이러한 결과를 일반화하기 어렵다는 한 계가 있다. 각 논문별 연구결과로 보고된 효과가 실제 교육현장에서 얼마나 지속되고 활용 가능 한지를 판단하기 위하여 프로그램 진행자 정보, 프로그램 실시 장소, 추수연구 진행 여부 등을 추가로 조사할 필요가 있다. 집단 프로그램의 효과는 진행자의 역량에 따라 큰 차이를 보이므로 진행자에 대한 정보가 누락되면 연구결과(프로그램 효과)에 대한 신뢰를 잃게 된다. 프로그램의 시행 장소 역시 프로그램의 효과에 중요한 영향을 미치는 요소로서, 연구 장소와 실제 적용되는 현장이 달라질 경우 동일한 효과를 기대하기 어렵다. 특히 예방 프로그램을 실시하는 목적은 일 시적인 변화가 아닌 효과의 지속적인 유지이므로 추수연구를 진행하고 이에 대한 결과를 보고 할 필요가 있다.

셋째, 프로그램 실시기간에 따른 효과크기의 차이는 장기적인 프로그램의 개발과 지속적인 운영의 중요성을 보여준다. 분석된 프로그램 중 $57 \%$ 가 1 10회기 이내의 짧은 회기동안 진행되 었고, 나머지 연구의 프로그램도 11 회기 이상 진행되었으나 6개월 1 년간 장기적으로 이루어지 거나 프로그램이 마무리 된 후 정기적으로 또 다른 대안 프로그램이 진행된 경우는 없었다. 단기 
프로그램은 일시적인 변화를 가져오는 것은 가능하지만, 일정 기간이 경과한 이후 정기적으로 프로그램을 다시 적용하는 등의 또 다른 대책이 필요하다. Hahn 등(2007)은 단지 연구를 위한 프로그램 운영이 아니라 상시로 운영되는 프로그램의 중요성을 강조하고 있다. 학교폭력을 예방 하고 근절하기 위해서는, 이들 프로그램의 효과성을 지속시키고 극대화할 수 있는 방안들을 모 색해야 할 것이다.

넷째, 현장연구와 실험연구의 차이점 중의 하나는 연구에 참여하는 대상자들의 특성일 것이 다. 연구에 필요한 대상자를 선정하기 위해서는 꾸준히 학교에 등교하는 학생이어야 하고, 참여 자들은 여러 회기의 프로그램을 진행하는 동안 빠지지 않고 참석하여 교사나 진행자의 지시를 잘 따라야 한다. 그런데 이러한 대상자의 선정 조건에서 심각한 품행 문제를 일으켜 퇴학이나 강제 전학, 정학 등의 조치를 받은 학생은 우선적으로 제외될 가능성이 높으며, 만일 프로그램에 참여하게 된다 하더라도 잦은 결석으로 인해 부실한 중재가 이루어지거나 진행자의 지시를 거 부하여 프로그램을 끝까지 이수하지 못할 가능성이 높다. 따라서 이러한 극단적인 성향의 학생 은 선행연구의 최종데이터에 포함되지 못했을 가능성이 높으며, 이러한 점이 프로그램의 효과가 실제보다 더 높게 나타나는 데 작용했을 수 있다. 따라서 추후 프로그램 운영 시, 일반학생뿐만 아니라 고위험군 학생들을 모두 포함하여 되도록 다양한 학생들을 대상으로 실시하고 이들 집 단에 따른 효과크기를 비교해볼 필요가 있다.

다섯째, 학교폭력은 한 가지 요인으로 발생한다기보다 환경적 요인과 다양한 심리적 요인이 복합적으로 상호작용하여 나타나는 현상이다. 그러나 예방 프로그램은 이러한 환경적 요인에 개 입하는 것이 어렵고, 또한 여러 가지 심리적 요인들 중 일부에만 개입할 수 있다는 한계가 있다. 단기적인 심리적 개입은 이루어질 수 있으나, 학교폭력의 복합근거가 되는 환경적 요인에서는 변화가 없으므로 다시 폭력이 재발되는 현상이 발생하는 것이다. 이를 보완하기 위해서는 지속 적으로 다양한 형태의 프로그램을 실시하는 한편, 부모교육, 다양한 경제적 지원, 유해환경 접촉 차단, 학교생활 적응훈련 등의 환경적 요인에 대한 개입이 동시에 이루어져야 할 것이다. 이러한 이유로, 외국의 경우 단발성의 프로그램보다는 지역사회와 학교가 함께 동참하는 학교 기반의 장기적인 프로그램을 더욱 강조하고 있다. 장기 프로그램은 효과가 나타나는 데 더 많은 시간과 노력이 필요하지만, 그만큼 나타나는 효과가 더욱 크고 지속적이라고 할 수 있다. 이 연구에서 비록 예방 프로그램의 효과크기가 크게 나타난 점이 고무적이라 할지라도, 단발성 효과가 아닌 지속적 효과가 나타나도록 하기 위해서는 다양한 교육주체간의 협력과 심리내 · 외적 요인의 조 절과 개입이 모두 필요함을 인식해야 한다.

학교폭력 문제가 날이 갈수록 그 심각성이 커지고 있다. 따라서 개인적인 연구 차원뿐만 아니 라 국가 차원에서도 다양한 프로그램을 개발하여 보급할 필요가 있다. 프로그램은 사후검사를 통해 그 효과성이 검증되어야 하고, 검증된 프로그램은 보다 많은 학생들이 혜택을 받을 수 있도 
록 확산될 필요가 있다. 이 연구는 기존에 이루어진 국내 학교폭력 예방 프로그램의 전반적인 효과와 성공요인, 시사점들을 논의하였으며, 이 부분을 보완하여 좀 더 효과적인 프로그램이 개 발될 수 있기를 기대해 본다. 


\section{참고문헌}

교육과학기술부(2012). 2012년 제1차 학교폭력 실태조사 결과.

고용남(2010). 독서치료 집단상담 프로그램의 효과에 대한 메타분석: 2001년-2008년 석 · 박사학 위논문을 중심으로. 석사학위논문, 평택대학교 상담대학원.

김경숙(1999). 부모의 양육태도와 가족관계에 대한 일반집단과 집단따돌림 가해 집단간의 비교 연구. 석사학위논문, 숭실대학교 .

김동일, 박알뜨리, 이기정(2008). 초등학생 학교 폭력 및 집단 따돌림 예방을 위한 대인관계 증진 게임 효과성 평가 연구. 아시아교육연구, 9(2), 49-65.

김윤지(2007). 인지행동 집단상담이 아동의 불안감소에 미치는 효과에 관한 메타분석. 석사학위

논문, 계명대학교.

김종미(2004). 한국 청소년 범죄의 실태와 대책방안. 석사학위논문, 용인대학교.

김현정(2013). 초등학교 저학년을 위한 학교폭력 예방프로그램의 효과 연구. 석사학위 논문, 한 국상담대학원대학교.

김혜진(2002). 학교폭력 예방 프로그램의 개발과 그 효과 - 학교폭력에 대한태도와 사회적, 심리

적 학교환경지각. 석사학위논문, 전남대학교.

도기봉(2007). 학교폭력을 경험한 여학생들의 문제와 집단 프로그램의 지속적인 개입 효과. 복지

행정론총, 17(2), 93-113

박송지(2010). 중학생대상 학교폭력 예방교육이 학교폭력태도 변화에 미치는 영향. 석사학위논

문, 광운대학교 상담복지정책대학원 .

박승민(2009). 청소년 인터넷 중독 집단상담 프로그램의 효과에 대한 메타분석. 한국심리학회

지: 상담 및 심리치료, 21(3), 607-623.

박영신, 김의철(2001). 학교폭력과 인간관계 및 청소년의 심리 행동특성: 폭력가해, 폭력피해, 폭

력무경험 집단의 비교를 중심으로. 한국심리학회지: 사회문제, 7(1), 63-89.

박은숙(2008). 에니어그램을 활용한 학교폭력 예방프로그램이 학교폭력가해학생의 대인관계 향 상에 미치는 효과. 석사학위논문, 창원대학교.

삼성생명공익재단 사회정신건강연구소(2005). 한 번 더 생각해봐 프로그램. 서울: 교육과학사. 서미경(2007). 중학생 학교폭력 예방 프로그램의 효과 연구. 석사학위논문, 성산효대학원대학교. 서울대학교 발달심리연구소(2005). 시우보우 프로그램.

서울대학교 발달심리연구소(2005). 헬핑 프로그램.

서춘래(2007). REBT 집단상담이 초등학생의 학교폭력행동에 미치는 효과. 박사학위논문, 서남대학교. 
양미진, 김은영, 이상희(2008). 초등학생의 학교폭력 예방을 위한 배려증진 프로그램 개발. 청소 년상담연구, 2008, 1-194.

양야기(2009). 학교폭력 예방 프로그램이 중학생의 학교폭력태도, 분노 및 공격성에 미치는 효

과. 박사학위논문, 전남대학교.

여성가족부(2011). 청소년백서.

유평수(2005). 중학생 학교폭력 예방 프로그램의 효과 분석. 청소년학연구, 12(2), 51-76.

이규미, 이대식, 김영혜(2003). 심각한 폭력(살인) 가해 학생에 대한 사례분석: 폭력 유발 요인과

예방안. 한국심리학회지: 상담 및 심리치료, 15(2), 367-382.

이은미(2000). 청소년 학교폭력의 요인연구. 석사학위논문, 가톨릭대학교 사회복지대학원.

이은희, 김혜진, 홍경자(2002). 청소년들의 학교폭력 예방을 위한 집단상담 프로그램의 효과. 상

담학연구, 3(1), 185-202.

이정희(2011). 전래놀이를 적용한 집단 프로그램이 아동의 학교폭력태도와 학교 만족도에 미치

는 효과. 석사학위논문, 대전대학교.

이창숙(2012). 학교폭력 예방프로그램이 학교폭력태도, 공격성 및 자기존중감에 미치는 효과. 박 사학위논문, 경상대학교.

이채원(2013). 학교폭력예방을 위한 어울림프로그램이 청소년의 자아존중감, 학급응집력 및 학 교폭력태도에 미치는 효과. 박사학위논문, 창원대학교.

이훈구, 권준모, 곽금주, 김범준, 홍영오(2000). 학원폭력 예방프로그램 연구 보고서. 국무총리 청소년보호위원회.

임영아(2013). 근거중심사회복지실천을 위한 노인미술치료 효과에 대한 메타분석. 박사학위논 문, 조선대학교.

임정란(2013). 학교폭력에 방관적인 초등학생의 공감능력 향상에 미치는 학교폭력예방프로그램

의 개발과 그 효과에 관한 연구. 석사학위논문, 호남신학대학교.

장금순(2005). 민속놀이를 활용한 초등학생 학교폭력 예방 프로그램 개발 연구. 박사학위논문, 숙명여자대학교.

장명희(2012). 아동 - 청소년을 대상으로 한 현실치료 집단상담 효과에 관한 메타분석. 석사학위 논문, 경성대학교.

정성희, 송현주(2012). 초등학교 3학년을 대상으로 무용 동작심리치료프로그램을 활용한 학교폭 력예방 프로그램의 효과. 심리치료: 다학제적 접근, 12(2), 125-147.

정진희(2009). 학교기반 학교폭력 예방프로그램의 효과성 분석에 관한 연구. 석사학위논문, 한양 대학교.

정혜승(2008). 진로 집단상담 프로그램이 학교폭력 예방에 미치는 영향. 석사학위논문, 이화여자 대학교 교육대학원. 
조성호(1999). 학교폭력에 대한 심리학적 개입의 허와 실: 국내 사례를 중심으로. 한국심리학회 대외심포지움 발표집, 41-54.

청소년폭력예방재단(2012). 2011년 전국 학교폭력 실태조사 발표 및 경향.

최운선(2005). 학교폭력 관련변인에 관한 메타분석. 한국가족복지학, 10(2), 95-111.

탁안희(2012). 학교폭력예방프로그램이 초등학교 4학년 아동의 공격성 감소에 미치는 영향. 석 사학위논문, 한양대학교 교육대학원.

한숙경(2007). 학교폭력예방 프로그램이 실업계고교생의 분노조절 및 자아존중감에 미치는 효 과. 석사학위논문, 동아대학교 교육대학원.

허승희, 최태진(2008). 초등학교 폭력예방을 위한 집단상담 프로그램의 적용과 그 효과. 초등교 육연구, 21(3), 175-197.

홍현정(2008). 학교폭력 예방프로그램이 남자 중학생의 분노조절에 미치는 효과. 석사학위논문, 창원대학교.

황진아(2010). 학교폭력에 영향을 미치는 요인에 관한 연구: 이천·여주지역 중학생을 대상으로. 석사학위논문, 동국대학교.

Bandura, A. (1973). Aggression: A social learning analysis. Englewood Cliff, NJ: Prentice-Hall. Borenstein, M., Hedges, L. V., Higgins, J. P. T,, \& Rothstein, H. R. (2009). Introduction to meta analysis. Wiley-Blackwell.

Cohen, J. (1992). Statistical power analysis for the behavioral sciences. New York: Academic Press. Dykeman, C., Daehlin, W., Doyle, S., \& Flamer, H. S. (1996). Psychological predictors of school-based violence: Implications for school counselors. The School Counselor, 44(1), 35-47.

Derzon, J. H., \& Wilson, S. J. (1999). An empirical review of school-based programs to reduce violence Paper presented at the annual meeting of the American Society of Criminology, Toronto, Canada.

Glass, G. V. (1976). Primary, secondary, and meta-analysis in social research Beverly Hills, CA: Sage.

Hahn, R., Fuqua-Whitley, D., Wethington, H., Lowy, J., Crosby, A., Fullilove, M., Johnson, R., Liberman, A., Moscicki, E., Price, L., Snyder, S., Tuma, F., Cory, S., Stone, G., Mukhopadhaya, M., Chattopadhyay, \& S., Dahlberg, L. (2007). Effectiveness of universal school-based programs to prevent violent and aggressive behavior: A systematic review. American Journal of Preventive Medicine, 33, 114-129.

Hedges, L. V., \& Olkin, I. (1985). Statistical methods for meta-analysis. Orlando, FL: Academic Press. 
Ladd, G. W., \& Ladd, B. K. (1998). Parenting behaviors and parent-child relationships: Correlates of peer victimization in kindergarten? Developmental Psychology, 34(6), 1450-1458.

Marano, H, E. (1995). Big, bad, bully. Psychology Today, 28(5), 50.

Morris, S. B., \& Deshon, R. P. (2002). Combining effect size estimates in meta-analysis with repeated measures and independent-groups designs. Psychological Methods, 7, 105-125.

Mytton, J. A., Diguiseppi, C., Gough, D., Taylor, R. S., \& Logan, S. (2002). School-based violence prevention programs: Systematic review of secondary prevention trials. Archives of Pediatrics and Adolescent Medicine, 156, 752-762.

Ngwe, J., Liu, I. C., Flay, B. R., \& Segawa, E. (2004). Violence prevention among African American adolescent males. American Journal of Health Behavior, 28, 524-537.

Olweus, D. (1993). Bullying at school: What we know and what we can do Oxford, UK: Blackwell. Olweus, D. (1994). Bullying at school: Basic facts and effects of a school based intervention program. Journal of Child Psychology and Psychiatry, 35(7), 1171-1190.

Olweus, D. (1997). Bully/victim problems in school: Knowledge base and an effective intervention program. Irish Journal of Psychology, 18(2), 170-190.

Orwin, R. G. (1983). A fail-safe $\mathrm{N}$ for effect size in meta-analysis. Journal of Educational Statistics, $8(2), 157-159$.

Park-Higgerson, H., Perumean-Chaney, S. E., Bartolucci, A. A., Grimely, D. M., \& Singh, K. P. (2008). The evaluation of school-based violence prevention programs: A meta-analysis. Journal of School Health, 78(9), 465-520.

Rigby, K., \& Slee, P. T. (1991). Bullying among Australian school children: Reported behavior and attitudes toward victims. Journal of Social Psychology, 131(5), 615-627.

Salmivalli, C. (1998). Intelligent, attractive, well-behaving, unhappy: The structure of adolescents' self-concept and its relations to their social behavior. Journal of Research on Adolescence, 8(3), 333-354.

Sprinkle, J. E. (2005). Animals, empathy, and violence: An evaluation of a school-based violence-prevention program in select South Carolina elementary and middle schools. Unpublished doctoral dissertation. University of South Carolina.

Vazsonyi, A. T., Belliston, L. M., \& Flannery, D. J. (2004). Evaluation of a school-based, universal violence prevention program: Low-, medium-, and high-risk children. Youth Violence and Juvenile Justice, 2(2), 185-206. 
* 논문접수 2014년 2월 11일 / 1차 심사 2014년 3월 14일 / 게재승인 2014년 3월 21일

* 윤초희: 연세대학교 교육학과를 졸업하고, 워싱턴 대학교 대학원 교육심리 전공 철학박사학위를 취득하였다. 현재 동국대학교 교육학과 교수로 재직 중이다. 주요논문 및 저서로는 '은유를 통해 본 대학생의 글쓰기신념' '사고와 언어(L. S. 비고츠키 [저]/A. 코즐린[편집])' 등이 있다.

* E-mail: chyoon@dongguk.edu

* 박상근: 동국대학교 교육대학원 상담심리 전공 석사학위를 취득하였다.

* E-mail: paa22@naver.com

* 신인수: 연세대학교 교육학과를 졸업하고, 플로리다 주립대학교 대학원 측정 및 통계 전공 철학박사학위를 취득하였다. 현재 전주대학교 교육학과 교수로 재직 중이다. 주요논문 및 저서로는 'The relationship between research self-efficacy and other research constructs: Synthesizing evidence and developing policy implications through meta-analysis', '교육학 연구방법으로서 메타분석의 발전과정 고찰 등이 있다.

* E-mail: s9065031@jj.ac.kr 
Abstract

\title{
A Meta-Analysis of the Effects of School Violence Prevention Programs in Korea
}

\author{
Yoon, Cho-Hee* \\ Park, Sang-Geun** \\ Shin, In-SoO***
}

This study purports to evaluate the effectiveness of school violence prevention programs and to identify the success factors of these programs. To search for the previous studies, we searched through web databases including keris, nanet, kiss, dapia, the Korean Psychology Association, etc., using as key words school violence, aggressiveness, bullying, delinquency, perpetrators, victims, prevention, and effect size. We selected a total of 23 publications including journal articles, theses, and dissertations which employed a pretest-posttest control group design and standardized measurement tools. A total of 96 effect size values were calculated by using the CMA(Comprehensive Meta Analysis) V2 program. The results show that the total program effect size value based on the random effect model was high. The analysis of effect sizes as to program characteristics reveal that the effect size values for intensive awareness-evoking programs were significantly higher than those for programs which attempted to indirectly intervene the participants' psychological traits. Such program strategies were associated with not only a reduction in violent behavior but also enhanced social-emotional skills. It was also shown that as the total number of sessions increased, the effect size values became significantly higher. Small group activities focused on high school students had a larger effect size value. Based on the findings, implications for future research and program implementation were discussed.

Key words: School violence, Prevention program, Effect size, Meta-analysis

\footnotetext{
* First author, Professor, Dongguk University

** Second author

*** Third author, Professor, Jeonju University
} 